\title{
THE INFLUENCE OF AIR-ABRASIVE TRIMMING ON THE CURRENT NOISE OF THICK FILM RESISTORS
}

\author{
YING-NAM LAI and JUINN-JEY CHANG \\ Department of Electrical Engineering, National Taiwan University, Taipei, Taiwan
}

\begin{abstract}
The purpose of this study was to investigate the effect of some air abrasive trim cuts on the current noise ot thick film resistors. It was found that the current noise changed on trimming the resistors and that the percentage change in the current noise enabled important conclusions to be drawn. From these conclusions it was possible to specify optimum trim cuts for resistors for high power and high frequency thick film hybrid circuits.
\end{abstract}

\section{INTRODUCTION}

The vast majority of resistors used in hybrid circuits need to be trimmed by one technique or another. This trimming results in a change in current noise in the resistor, and as current noise is an important figure of merit in high power and high frequency thick film hybrid circuits, it was thought necessary to investigate the relationship between trimming and current noise.

It has previously been shown, Refs. 1 and 2 , that the more uniform the current distribution is, the less will be the current noise. Different cuts required for trimming will give rise to different non-uniform current distributions in resistors and, therefore, the current noise will vary from resistor to resistor due to the different cuts, different materials and the different substrates used.

\section{RESULTS}

The experimental results for two types of cuts are given in Tables I to IV. These results were obtained with two trimming configurations, namely the straight trimmed cut of length $\mathrm{W} / 2$, or the straight trimmed cut of length $\mathrm{W} / 3$ (see Figure 1.). Test pattern using fixed resistors have been employed (see Figure 2.). The dimensions of the resistors are $1: 1(0.3 \mathrm{~cm} \times 0.3 \mathrm{~cm})$,

$1: 1(0.5 \mathrm{~cm} \times 0.5 \mathrm{~cm}), 1: 1(0.7 \mathrm{~cm} \times 0.7 \mathrm{~cm})$, $1: 1(0.9 \mathrm{~cm} \times 0.9 \mathrm{~cm}), 1: 3(0.4 \mathrm{~cm} \times 1.2 \mathrm{~cm})$, and $1: 2(0.4 \mathrm{~cm} \times 0.8 \mathrm{~cm})$.

Measurements of noise have also been taken on other cuts of the type shown in Figure 1.

The noise measurements were obtained using a model 315B Resistor Noise Test Set, Ref. 3. The conductor paste used was ESL9635, the resistor

TABLE I

Resistance (before trimming) where $a$ denotes standard deviation, $u$ denotes mean value. Nos. 1, 2, 3 and 4 are straight $W / 2$ trimming. Nos. 5, 6, 7 and 8 are straight $W / 3$ trimming.

\begin{tabular}{|c|c|c|c|c|c|c|}
\hline No. & $\begin{array}{l}1: 1 \\
0.3 \mathrm{~cm} \times 0.3 \mathrm{~cm}\end{array}$ & $\begin{array}{l}1: 1 \\
0.5 \mathrm{~cm} \times 0.5 \mathrm{~cm}\end{array}$ & $\begin{array}{l}1: 1 \\
0.7 \mathrm{~cm} \times 0.7 \mathrm{~cm}\end{array}$ & $\begin{array}{l}1: 1 \\
0.9 \mathrm{~cm} \times 0.9 \mathrm{~cm}\end{array}$ & $\begin{array}{l}1: 3 \\
0.4 \mathrm{~cm} \times 1.2 \mathrm{~cm}\end{array}$ & $\begin{array}{l}1: 2 \\
0.4 \mathrm{~cm} \times 0.8 \mathrm{~cm}\end{array}$ \\
\hline 1 & 1.57 & 1.49 & 1.70 & 1.82 & 0.59 & 0.81 \\
\hline 2 & 1.27 & 1.48 & 1.50 & 1.65 & 0.51 & 0.71 \\
\hline 3 & 1.50 & 1.18 & 1.65 & 1.76 & 0.54 & 0.67 \\
\hline 4 & 1.43 & 1.39 & 1.56 & 1.60 & 0.52 & 0.71 \\
\hline 5 & 1.34 & 1.33 & 1.48 & 1.61 & 0.50 & 0.67 \\
\hline 6 & 1.20 & 1.45 & 1.50 & 1.53 & 0.45 & 0.73 \\
\hline 7 & 1.09 & 1.41 & 1.37 & 1.27 & 0.49 & 0.63 \\
\hline 8 & 1.39 & 1.36 & 1.60 & 1.61 & 0.47 & 0.69 \\
\hline$a$ & 0.148 & 0.0939 & 0.0982 & 0.154 & 0.0404 & 0.0499 \\
\hline$u$ & 1.349 & 1.386 & 1.545 & 1.606 & 0.509 & 0.703 \\
\hline$a / u$ & 0.1091 & 0.0677 & 0.0636 & 0.0959 & 0.0794 & 0.0710 \\
\hline
\end{tabular}

Unit: K ohms. 
TABLE II

Resistance (after trimming) Nos. 1, 2, 3 and 4 are straight $W / 2$ trimming, Nos. 5, 6, 7, and 8 are straight $W / 3$ trimming.

\begin{tabular}{lllllll}
\hline No. & $1: 1$ & $1: 1$ & $1: 1$ & $1: 1$ & $1: 3$ & $1: 2$ \\
\hline 1 & 2.41 & 2.29 & 2.41 & 2.71 & 1.00 & 1.40 \\
2 & 1.84 & 2.39 & 2.12 & 2.41 & 0.95 & 1.25 \\
3 & 2.29 & 1.73 & 2.45 & 2.55 & 1.03 & 1.22 \\
4 & 2.36 & 1.96 & 2.33 & 2.55 & 1.00 & 1.19 \\
5 & 1.84 & 1.59 & 1.69 & 1.88 & 0.64 & 0.87 \\
6 & 1.57 & 1.82 & 1.80 & 1.93 & 0.59 & 0.91 \\
7 & 1.31 & 1.70 & 1.72 & 1.57 & 0.70 & 0.84 \\
8 & 1.65 & 1.79 & 2.03 & 2.06 & 0.73 & 0.94 \\
\hline
\end{tabular}

Unit: K ohms.

TABLE III

Before and after trimming (current noise) BT denotes before trimming. AT denotes after trimming.

Nos. 1, 2, 3 and 4 are straight $W / 2$ trimming. Nos. 5, 6, 7 and 8 are straight $W / 3$ trimming.

\begin{tabular}{|c|c|c|c|c|c|c|c|c|c|c|c|c|c|}
\hline \multirow[b]{2}{*}{ No. } & & \multicolumn{2}{|l|}{$1: 1$} & \multicolumn{2}{|l|}{$1: 1$} & \multicolumn{2}{|l|}{$1: 1$} & \multicolumn{2}{|l|}{$1: 1$} & \multicolumn{2}{|l|}{$1: 3$} & \multicolumn{2}{|l|}{$1: 2$} \\
\hline & & BT & AT & BT & AT & BT & AT & BT & $\mathrm{AT}$ & BT & AT & BT & AT \\
\hline 1 & $\begin{array}{l}S \\
D \\
T \\
f(T-S) \\
I\end{array}$ & $\begin{array}{c}-2 \\
21.7 \\
4 \\
1.2 \\
-18.9\end{array}$ & $\begin{array}{c}-7 \\
23.4 \\
9.5 \\
0 \\
-13.9\end{array}$ & $\begin{array}{c}-2 \\
21.7 \\
1 \\
3 \\
-23.7\end{array}$ & $\begin{array}{c}-7.5 \\
23.4 \\
5 \\
0.3 \\
-18.7\end{array}$ & $\begin{array}{r}-1 \\
22.5 \\
0.5 \\
5.3 \\
-27.3\end{array}$ & $\begin{array}{r}-7 \\
23.4 \\
1.5 \\
0.6 \\
-22.5\end{array}$ & $\begin{array}{r}-0.5 \\
22.5 \\
0.5 \\
6.6 \\
-28.6\end{array}$ & $\begin{array}{r}-6 \\
24.3 \\
0.5 \\
1.1 \\
-24.9\end{array}$ & $\begin{array}{r}-8.5 \\
17.5 \\
-5.5 \\
3 \\
-26\end{array}$ & $\begin{array}{l}-12.5 \\
20 \\
-2.5 \\
0.5 \\
-23\end{array}$ & $\begin{array}{r}-7 \\
19.2 \\
-3.5 \\
2.6 \\
-25.3\end{array}$ & $\begin{array}{r}-10.5 \\
21.7 \\
1.5 \\
0.3 \\
-20.5\end{array}$ \\
\hline 2 & $\begin{array}{l}S \\
D \\
T \\
f(T-S) \\
I\end{array}$ & $\begin{array}{c}-4 \\
20.8 \\
2 \\
1.2 \\
-20\end{array}$ & $\begin{array}{c}-8.5 \\
22.5 \\
6 \\
0 \\
-16.5\end{array}$ & $\begin{array}{r}-2.5 \\
21.7 \\
0.6 \\
2.9 \\
-24\end{array}$ & $\begin{array}{r}-7 \\
23.4 \\
3.8 \\
0.4 \\
-20\end{array}$ & $\begin{array}{c}-2.5 \\
21.7 \\
-1 \\
5.2 \\
-27.9\end{array}$ & $\begin{array}{r}-7.5 \\
23.4 \\
0.5 \\
0.7 \\
-23.6\end{array}$ & $\begin{array}{r}-1.5 \\
22.5 \\
-0.5 \\
6.6 \\
-29.6\end{array}$ & $\begin{array}{c}-7 \\
23.4 \\
-1 \\
1.2 \\
-25.6\end{array}$ & $\begin{array}{r}-10.5 \\
17.5 \\
-6.5 \\
2.3 \\
-26.2\end{array}$ & $\begin{array}{l}-12.5 \\
20 \\
-2.5 \\
0.5 \\
-23\end{array}$ & $\begin{array}{r}-8 \\
18.3 \\
-4.5 \\
2.6 \\
-25.4\end{array}$ & $\begin{array}{r}-11 \\
20.8 \\
-0.5 \\
0.4 \\
-21.7\end{array}$ \\
\hline 3 & $\begin{array}{l}S \\
D \\
T \\
f(T-S) \\
I\end{array}$ & $\begin{array}{r}-2.5 \\
21.7 \\
3.0 \\
1.4 \\
-20.1\end{array}$ & $\begin{array}{c}-7 \\
23.4 \\
7.5 \\
0 \\
-15.9\end{array}$ & $\begin{array}{r}-4 \\
20.8 \\
-1.5 \\
3.6 \\
-25.9\end{array}$ & $\begin{array}{c}-9 \\
22.5 \\
1 \\
0.5 \\
-22\end{array}$ & $\begin{array}{r}-1.5 \\
22.5 \\
0.5 \\
4.2 \\
-26.2\end{array}$ & $\begin{array}{r}-6.5 \\
24.3 \\
2.5 \\
0.6 \\
-22.4\end{array}$ & $\begin{array}{c}-1 \\
22.5 \\
0 \\
6.6 \\
-29.1\end{array}$ & $\begin{array}{r}-6.5 \\
24.3 \\
0.5 \\
1 \\
-24.8\end{array}$ & $\begin{array}{r}-10 \\
17.5 \\
-6.2 \\
2.3 \\
-26.0\end{array}$ & $\begin{array}{c}-12 \\
20 \\
-3 \\
0.6 \\
-23.6\end{array}$ & $\begin{array}{r}-11 \\
18.3 \\
-5.5 \\
1.4 \\
-25.2\end{array}$ & $\begin{array}{r}-11 \\
20.8 \\
-1.5 \\
0.5 \\
-22.8\end{array}$ \\
\hline 4 & $\begin{array}{l}S \\
D \\
T \\
f(T-S) \\
I\end{array}$ & $\begin{array}{r}-5.5 \\
21.7 \\
2.5 \\
0.7 \\
-19.9\end{array}$ & $\begin{array}{c}-1 \\
23.4 \\
7.5 \\
0 \\
-15.9\end{array}$ & $\begin{array}{c}-5.5 \\
21.7 \\
-1 \\
1.9 \\
-24.6\end{array}$ & $\begin{array}{r}-8 \\
22.5 \\
2.5 \\
0.4 \\
-20.1\end{array}$ & $\begin{array}{c}-4.5 \\
21.7 \\
-1.5 \\
3 \\
-26.2\end{array}$ & $\begin{array}{r}-7.5 \\
23.4 \\
1.5 \\
0.6 \\
-22.5\end{array}$ & $\begin{array}{c}-4 \\
21.7 \\
-2 \\
4.2 \\
-27.9\end{array}$ & $\begin{array}{r}-6.5 \\
24.3 \\
0.5 \\
0.9 \\
-24.7\end{array}$ & $\begin{array}{r}-11.5 \\
17.5 \\
-6.5 \\
1.6 \\
-25.6\end{array}$ & $\begin{array}{l}-12 \\
20 \\
-2.5 \\
0.5 \\
-23\end{array}$ & $\begin{array}{c}-10 \\
18.3 \\
-5 \\
1.6 \\
-24.9\end{array}$ & $\begin{array}{r}-11.5 \\
20.8 \\
-0.5 \\
0.4 \\
-21.7\end{array}$ \\
\hline 5 & $\begin{array}{l}S \\
D \\
T \\
f(T-S) \\
I\end{array}$ & $\begin{array}{r}-5.5 \\
20.8 \\
2 \\
0.8 \\
-19.6\end{array}$ & $\begin{array}{c}-9 \\
22.5 \\
6 \\
0 \\
-16.5\end{array}$ & $\begin{array}{c}-5.5 \\
20.8 \\
-2 \\
2.6 \\
-25.4\end{array}$ & $\begin{array}{r}-9.5 \\
21.7 \\
-0.5 \\
0.5 \\
-22.7\end{array}$ & $\begin{array}{r}-4.5 \\
21.7 \\
-2.5 \\
4.2 \\
-28.4\end{array}$ & $\begin{array}{c}-9.5 \\
22.5 \\
-2.5 \\
1 \\
-26.0\end{array}$ & $\begin{array}{c}-4 \\
21.7 \\
-3 \\
6.6 \\
-31.3\end{array}$ & $\begin{array}{c}-8.5 \\
22.5 \\
-3 \\
1.4 \\
-26.9\end{array}$ & $\begin{array}{c}-12.5 \\
16.7 \\
-9 \\
2.6 \\
-28.3\end{array}$ & $\begin{array}{r}-14.5 \\
18.3 \\
-6.5 \\
0.8 \\
-25.6\end{array}$ & $\begin{array}{r}-10.5 \\
18.3 \\
-6.5 \\
2.2 \\
-26\end{array}$ & $\begin{array}{r}-13 \\
19.2 \\
-4.5 \\
0.6 \\
-23.8\end{array}$ \\
\hline 6 & $\begin{array}{l}S \\
D \\
T \\
f(T-S) \\
I\end{array}$ & $\begin{array}{c}-9.5 \\
20.8 \\
1 \\
0.4 \\
-20.2\end{array}$ & $\begin{array}{c}-9.5 \\
21.7 \\
4 \\
0.1 \\
-17.9\end{array}$ & $\begin{array}{c}-8 \\
21.7 \\
-1.5 \\
1 \\
-24.2\end{array}$ & $\begin{array}{r}-9.0 \\
22.5 \\
1.5 \\
0.4 \\
-21.4\end{array}$ & $\begin{array}{c}-8 \\
21.7 \\
-4 \\
2.2 \\
-27.9\end{array}$ & $\begin{array}{c}-8.5 \\
22.5 \\
-1.5 \\
1 \\
-25.0\end{array}$ & $\begin{array}{c}-8 \\
21.7 \\
-5 \\
3 \\
-29.7\end{array}$ & $\begin{array}{r}-8.0 \\
22.5 \\
-2.5 \\
1.4 \\
-26.4\end{array}$ & $\begin{array}{c}-15.5 \\
16.7 \\
-10 \\
1.4 \\
-28.1\end{array}$ & $\begin{array}{r}-15 \\
17.5 \\
-7.5 \\
0.8 \\
-25.8\end{array}$ & $\begin{array}{c}-12.5 \\
18.3 \\
-6 \\
1 \\
-25.3\end{array}$ & $\begin{array}{r}-13 \\
19.2 \\
-45 \\
0.6 \\
-24.3\end{array}$ \\
\hline 7 & $\begin{array}{l}S \\
D \\
T \\
f(T-S) \\
I\end{array}$ & $\begin{array}{c}-7.5 \\
20 \\
0 \\
0.8 \\
-20.8\end{array}$ & $\begin{array}{c}-10 \\
20.8 \\
3 \\
0.2 \\
-18\end{array}$ & $\begin{array}{c}-7 \\
21.7 \\
-2 \\
1.6 \\
-25.3\end{array}$ & $\begin{array}{c}-9 \\
22.5 \\
1 \\
0.5 \\
-22\end{array}$ & $\begin{array}{r}-7 \\
21.7 \\
-3.5 \\
2.6 \\
-27.8\end{array}$ & $\begin{array}{r}-9 \\
22.5 \\
-1.5 \\
0.4 \\
-24.4\end{array}$ & $\begin{array}{c}-7 \\
20.8 \\
-5 \\
4.2 \\
-30\end{array}$ & $\begin{array}{c}-10 \\
21.7 \\
-5 \\
1.6 \\
-28.3\end{array}$ & $\begin{array}{c}-13.5 \\
16.7 \\
-9 \\
1.9 \\
-27.6\end{array}$ & $\begin{array}{r}-14 \\
18.3 \\
-5.5 \\
0.6 \\
-24.4\end{array}$ & $\begin{array}{r}-12 \\
18.3 \\
-6.5 \\
1.4 \\
-26.2\end{array}$ & $\begin{array}{r}-13 \\
19.2 \\
-4.5 \\
0.6 \\
-24.3\end{array}$ \\
\hline 8 & $\begin{array}{l}S \\
D \\
T \\
f(T-S) \\
I\end{array}$ & $\begin{array}{c}-8 \\
22.5 \\
1.5 \\
0 \\
-21\end{array}$ & $\begin{array}{c}-9.5 \\
22.5 \\
6 \\
0.1 \\
-16.6\end{array}$ & $\begin{array}{c}-8 \\
21.7 \\
-2 \\
1.2 \\
-24.5\end{array}$ & $\begin{array}{r}-7 \\
22.5 \\
2.5 \\
0.5 \\
-20.5\end{array}$ & $\begin{array}{r}-7 \\
21.7 \\
-3.2 \\
2.3 \\
-27.2\end{array}$ & $\begin{array}{r}-8 \\
23.4 \\
0.5 \\
0.7 \\
-23.6\end{array}$ & $\begin{array}{r}-7 \\
21.7 \\
-4.5 \\
3.5 \\
-29.7\end{array}$ & $\begin{array}{r}-8 \\
23.4 \\
-1.5 \\
0.8 \\
-25.7\end{array}$ & $\begin{array}{c}-14.5 \\
16.7 \\
-9 \\
1.5 \\
-27.2\end{array}$ & $\begin{array}{r}-13.5 \\
18.3 \\
-4.5 \\
0.7 \\
-23.5\end{array}$ & $\begin{array}{r}-12.5 \\
18.3 \\
-6.5 \\
1.2 \\
-26\end{array}$ & $\begin{array}{c}-12.5 \\
20 \\
-3 \\
0.5 \\
-23.5\end{array}$ \\
\hline
\end{tabular}


TABLE IV

The increased amounts and percentages of current noise.

Nos. 1, 2, 3 and 4 are straight $W / 2$ trimming. Nos. 5, 6, 7 and 8 are straight $w / 3$ trimming.

\begin{tabular}{rlcccccc}
\hline & & $1: 1$ & $1: 1$ & $1: 1$ & $1: 1$ & $1: 3$ & $1: 2$ \\
\hline 1 & $\Delta I$ & $5 \mathrm{~dB}$ & $5 \mathrm{~dB}$ & $4.8 \mathrm{~dB}$ & $3.7 \mathrm{~dB}$ & $3 \mathrm{~dB}$ & $4.8 \mathrm{~dB}$ \\
& $\%$ & $26.46 \%$ & $21.10 \%$ & $17.58 \%$ & $12.94 \%$ & $11.54 \%$ & $18.97 \%$ \\
2 & $\Delta I$ & $3.5 \mathrm{~dB}$ & $4.0 \mathrm{~dB}$ & $4.3 \mathrm{~dB}$ & $4.0 \mathrm{~dB}$ & $3.2 \mathrm{~dB}$ & $3.7 \mathrm{~dB}$ \\
& $\%$ & $17.50 \%$ & $16.67 \%$ & $15.41 \%$ & $13.51 \%$ & $12.21 \%$ & $14.57 \%$ \\
3 & $\Delta I$ & $4.2 \mathrm{~dB}$ & $3.9 \mathrm{~dB}$ & $3.8 \mathrm{~dB}$ & $4.3 \mathrm{~dB}$ & $2.4 \mathrm{~dB}$ & $2.4 \mathrm{~dB}$ \\
& $\%$ & $20.90 \%$ & $15.06 \%$ & $14.50 \%$ & $14.78 \%$ & $9.23 \%$ & $9.25 \%$ \\
4 & $\Delta I$ & $4.0 \mathrm{~dB}$ & $4.5 \mathrm{~dB}$ & $3.7 \mathrm{~dB}$ & $3.2 \mathrm{~dB}$ & $2.6 \mathrm{~dB}$ & $3.2 \mathrm{~dB}$ \\
& $\%$ & $20.10 \%$ & $18.29 \%$ & $14.12 \%$ & $11.47 \%$ & $10.16 \%$ & $12.85 \%$ \\
5 & $\Delta I$ & $3.1 \mathrm{~dB}$ & $2.7 \mathrm{~dB}$ & $2.4 \mathrm{~dB}$ & - & $2.7 \mathrm{~dB}$ & $2.2 \mathrm{~dB}$ \\
& $\%$ & $15.82 \%$ & $10.63 \%$ & $8.45 \%$ & - & $9.54 \%$ & $8.46 \%$ \\
6 & $\Delta I$ & $2.3 \mathrm{~dB}$ & $2.8 \mathrm{~dB}$ & $2.9 \mathrm{~dB}$ & - & $2.3 \mathrm{~dB}$ & $1.8 \mathrm{~dB}$ \\
& $\%$ & $11.39 \%$ & $11.57 \%$ & $10.39 \%$ & - & $8.19 \%$ & $7.11 \%$ \\
7 & $\Delta I$ & $2.8 \mathrm{~dB}$ & $3.3 \mathrm{~dB}$ & $3.4 \mathrm{~dB}$ & - & $3.2 \mathrm{~dB}$ & $1.9 \mathrm{~dB}$ \\
& $\%$ & $13.46 \%$ & $13.04 \%$ & $12.23 \%$ & - & $11.59 \%$ & $7.25 \%$ \\
8 & $\Delta I$ & $3.6 \mathrm{~dB}$ & $4.4 \mathrm{~dB}$ & $3.7 \mathrm{~dB}$ & - & $3.6 \mathrm{~dB}$ & $2.5 \mathrm{~dB}$ \\
& $\%$ & $17.82 \%$ & $17.67 \%$ & $13.60 \%$ & - & $13.28 \%$ & $9.62 \%$ \\
\hline
\end{tabular}

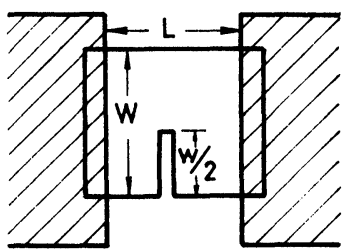

straight $(W / 2)$

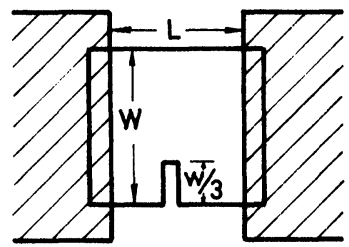

straight $(W / 2)$

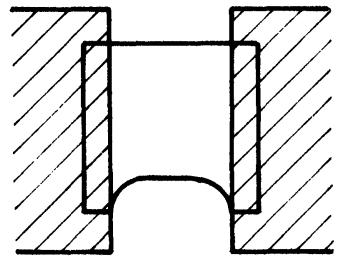

single edge

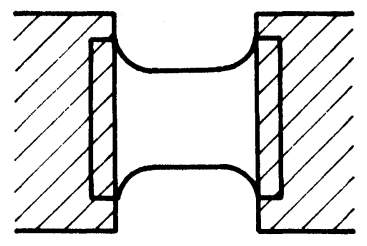

double edge

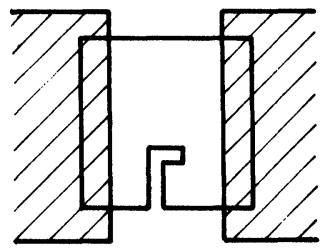

L-type cut

FIGURE 1 Trimming configurations.

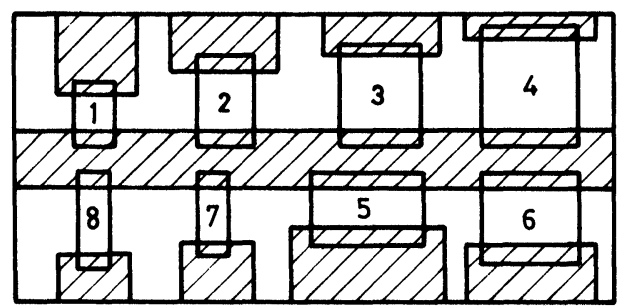

FIGURE 2 Test pattern. material ESL3813, and the trimming was done with a Comoco Trimming Machine.

\section{DISCUSSION}

Before trimming, the resistance deviation $a$ and the mean value $u$ was calculated and these are shown in Table I. From these calculations it was found that $a$ is just about $10 \%$ of $u$. This indicated that the printing of 
resistors was reproducible enough for the experimental work. Resistances of trimmed resistors is shown in Table II.

Before and after trimming the current noise of the resistors was measured and this is shown in Table III. In Table III $S$ notes the system noise in $\mathrm{dB}$ which is the background noise present in the resistor when no direct current is flowing, $T$ denotes the total noise in $\mathrm{dB}$, and $D$ is the noise produced by the DC applied voltage.

Both the DC voltage noise and the total noise was measured simultaneously, but when the DC voltage was applied to the terminals of the resistor under test, the associated noise measurement indicated the total noise in the resistor.

For resistors having only a small difference between total noise and system noise a correction factor $f(T-S)$ has to be applied. The relationship between this correction factor and $T-S$ is given by:

$$
f(T-S)=-10 \log \left(1-10^{-(T-S) / 10}\right)
$$

The current noise index $I$ is calculated using the formula:

$$
I(\text { in } \mathrm{dB})=T-f(T-S)-D
$$

The noise specifications for carbon film resistors are as follows: for $1 \mathrm{~K} \Omega$ resistor, max current noise is $-8 \mathrm{~dB}, 500 \Omega,-10 \mathrm{~dB}$ and $5 \mathrm{~K} \Omega,-5 \mathrm{~dB}$. It can be seen from Table III that the current noise of thick film resistors examined in the present experiment was less than that of carbon film resistors.

It can also be seen from Table III that for the resistors of the same aspect ratio the least current noise value is associated with largest resistance.

Furthermore current noise is largest in the smallest resistor, and smallest in the largest resistor. The main reason for this phenomena is thought to be due to the uniformity of current distribution in the large resistors.

After trimming it was found that the current noise in every resistor increased. Percentage increases are shown in Table IV. From Table IV it can be seen that for the straight trimmed cuts examined the noise increase was greatest in the smallest area resistors. These results can be explained from the fact that the influence of trimming on the current path in the resistors, for resistors with small areas is more serious than that with resistors of larger area. In other words the current distribution in the smaller resistors becomes more non-uniform on trimming so that the current noise increases by a larger percentage.
For $(W / 3)$ straight trimmed resistors, the increased percentage of current noise on trimming is much less than with the $(\mathrm{W} / 2)$ straight trimmed. Again this can be explained by the consideration of current distribution in the resistor; the disturbance of the current distribution in the former case is much less than in the latter. (see Table IV).

For $(\mathrm{W} / 2)$ straight trimming, the increased percentage of current noise for resistors with the aspect ratio 1:3, is the smallest observed (see Table III).

Finally, measurements have been made in a similar manner on the other trimmed cuts shown in Figure 1. Typical results are:

1) For single edged trimming the \% increase in current noise is only $67 \%$ of that observed with a straight trim.

2) For double edged trimming the \% increase in current noise is again only $67 \%$ of that obtained with a straight trim.

3) For L-cut trimming the increase of current noise is only $77 \%$ of that observed in straight trimming.

\section{CONCLUSIONS}

From the above results and discussions the following conclusions can be drawn:

1) For resistors with the same aspect ratio, the least current noise is obtained in the largest value resistors.

2) For straight trimmings, the farther the trimming cut goes into the resistor the higher is the increase current noise.

3) The increase in current noise for single edge trimming, double edge trimming and L-cut trimming is less than for straight trimming.

4) After trimming the current noise variations are in the range 10 to $30 \%$

\section{REFERENCES}

1. K. R. Bube and A. Z. Muller "Influence of laser-trim configuration on stability of small thick-film resistors" Solid State Technology, 21, 11, pp. 55-60 (1978).

2. T. M. Chen and J. G. Rhee "The effects of trimming on the current noise of thick film resistors", Solid State Technology, 20, 6, pp. 49-53 (1977).

3. Instruction Manual of Quan-Tech Model 315B Resistor Noise Test Set, pp. 2.1-2.8. 

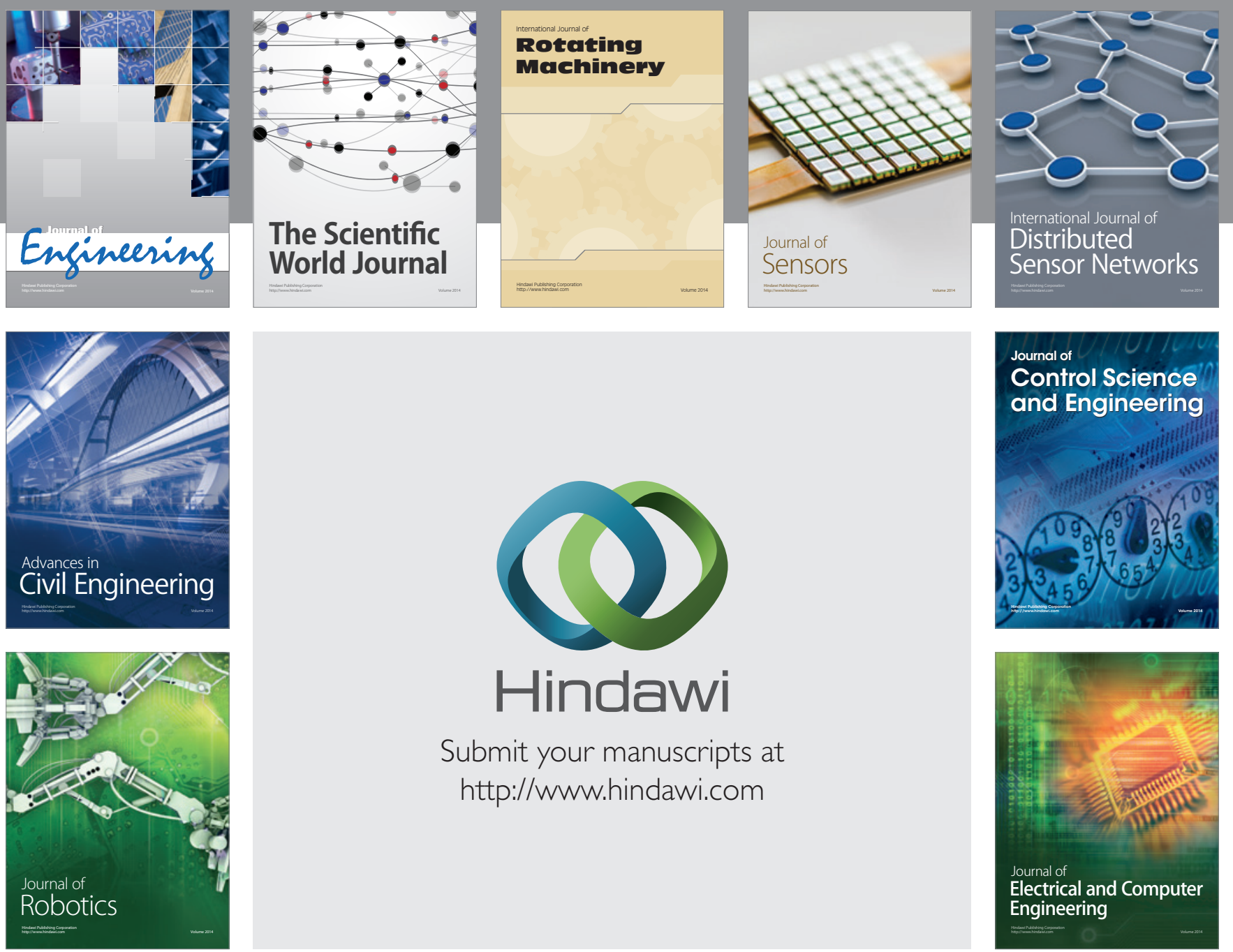

Submit your manuscripts at

http://www.hindawi.com
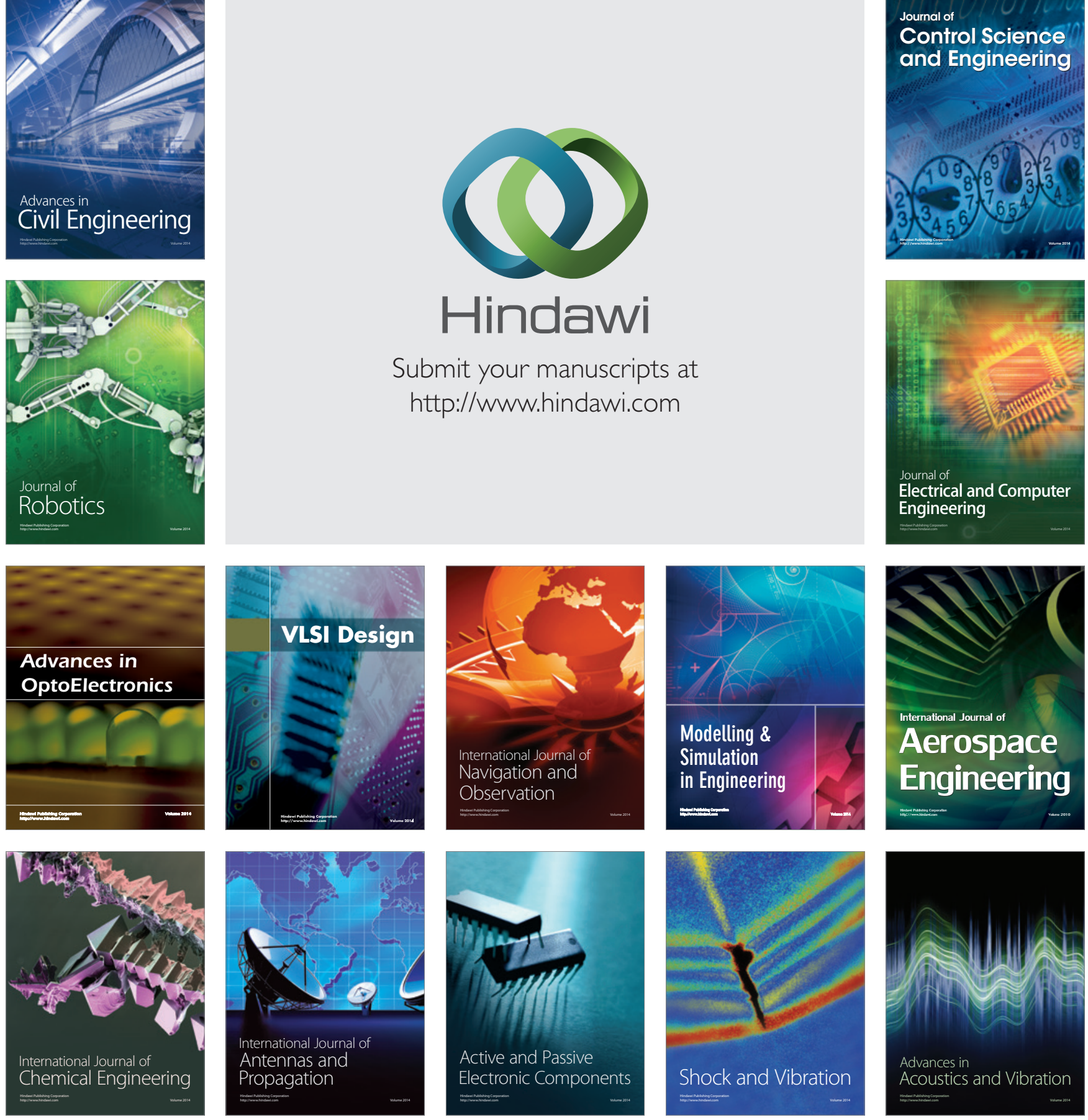